\title{
A Critical Note on Poverty Eradication Target of Sustainable Development Goals
}

\author{
Dr. Palash Kamruzzaman ${ }^{1}$
}

\begin{abstract}
Sustainable Development Goals (SDGs) aim big - as one of its target is to eradicate extreme poverty by 2030 for all people everywhere. This paper offers a critical review and outlines some potential challenges in achieving this noble target. In doing so, it offers a critical review of poverty scholarship to assess the notion of extreme poverty adopted in the SDGs. This also takes stock of past global anti-poverty programmes to set an appropriate context for forecasting potential challenges to eradicate poverty everywhere. It is highlighted that i) a number of poor countries will have to perform a magic against their track records, ii) the world needs to be consistently peaceful, iii) significant and equitable reform should take place within world economic structure, iv) quality and international comparability of poverty data in poor countries need to be improved significantly, and v) uncertainty about required investment in poor countries should be addressed rigorously in order for achieving poverty eradication target of the SDGs. These lead to the argument that without strong political commitments by all related stakeholders and an approach to look beyond existing models poverty eradication target may turn out to be another statement of good intentions by the international aid architecture with little meaningful practical relevance.
\end{abstract}

Key words: Poverty, poverty eradication, extreme poverty, sustainable development goals (SDGs), millennium development goals (MDGs), dollarisation of poverty, developing countries

\section{Introduction}

In September 2015, a new set of development goals have been agreed by 193 countries in a special summit at the United Nations (UN). These are called Sustainable Development Goals (SDGs) that aim to end poverty, achieve gender equality and ensure food security in every corner of the globe by 2030. These goals and targets (17 Goals and 169 targets) have been debated by civil society and UN member states for a considerable amount of time before finalising them ${ }^{1}$. This has led the Secretary General of the UN to

1 A UN System Task Team on post-2015 Development Agenda was set in January 2012 to coordinate preparations for next round of global development goals beyond 2015. The Task Team published its first report, Realizing the Future We Want for All, in June 2012. In June 2012, member governments agreed at the UN Conference on Environment and Development (Rio+20) on launching a UN-led process to create a set of universal SDGs. The Rio +20 outcome document titled The Future $W e W$ ant, and its endorsement led the UN to pursue consultation over the following two years by creating the Open Working Group (OWG) in June 2012. A High Level Panel (HLP) of eminent persons was set up by the Secretary General of the UN and the panel submitted its report on post-2015 development agenda in 2013. In brief, the outcome of Rio+20 document, the HLP report, and OWG proposals were the basis for approving the Sustainable Development Goals by the UN in September 2015 Summit. For a greater discussion on this topic please see UN (2015a), Sexsmith and McMichael (2015); Yiu and Saner (2014), and Palmer (2015).

${ }^{1}$ Department of Politics, Language \& International Studies, University of Bath, Claverton Down

Bath BA2 7AY, UK. 
claim that the SDGs are people's agenda, a plan of action for ending poverty in all its dimensions, irreversibly, everywhere, and leaving no one behind (Ki-moon 2015). The SDGs are built on the foundations of the Millennium Development Goals (MDGs), and seek to complete the unfinished business (of the MDGs), as well as respond to new challenges (UN, 2015a). Poverty eradication seems to be one of the main priorities of this grand framework as Hulme (2015) insists the SDGs have marked the end of development as poverty reduction. This paper focuses on Goal-1 of the SDGs: 'End poverty in all its forms everywhere'. To be more specific the first target of this goal that states:

By 2030, eradicate extreme poverty for all people everywhere, currently measured as people living on less than $\$ 1.25$ a day (UN, 2015b)

The change in the narrative of poverty 'eradication' in place of poverty 'reduction' has received much acclaims. Pogge and Sengupta (2015) assume that this might raise the gaze of politicians and officials beyond their usual preoccupations with short-term political advantage or narrowly defined national interest, leading them to think imaginatively about the future. However, at the same time, this might potentially turn out to be another popular slogan and/or development under-achievement ${ }^{2}$ as there are major pitfalls for achieving this goal. This paper offers a critical review of these challenges in pursuit of a world that is free of poverty.

The structure of the paper is like this: section-2 offers a critical review of poverty scholarship to assess the notion of extreme poverty adopted in the SDGs for poverty eradication. Section-3 elaborates what could be possible implications (for eradicating poverty) of the claim/achievement of halving the global number of extreme poor during the MDGs time period. Section-3 also explores where majority of extreme poor people live in a post-2015 world. This clearly builds a solid ground to forecast the challenges for eradicating extreme poverty everywhere as outlined in section-4. Finally, section-5 draws some conclusions.

\section{Legacy of Dollarised Poverty Continues}

This section critically looks at how extreme poverty is being conceptualised within the SDGs framework, particularly in its poverty eradication target. It also offers a critical assessment what this conceptualisation may mean for global poverty eradication. Poverty is a highly contested concept. There seem to be no single definition which is acceptable to all. Poverty can be perceived from various perspectives. For example, poverty can be explained in monetary terms, such as absolute (Roach and Roach, 1972; Hagenaars, 1991; MacPherson and Silburn, 1998; Rowntree 1941) and in relative forms (Townsend, 1970; Dandekar, 1981; Kambhapati, 2007). It can also be explained through assorted non-monetary features: such as capabilities approach (Nussbaum, 2000; Sen, 1976), social exclusion (Atkinson, 1998), chronic poverty (Baulch and Hoddinott, 2000; Hulme and Shepherd, 2003; Green and Hulme, 2005), famines and disasters ((Like-

2 I am not in favour of wholesale usage of the term development failure as past development initiatives may not have fulfilled promises they made, but there have been notable progress in several countries on various aspects (e.g. on poverty, health, sanitation, primary education, water supply, life expectancy, anti-natal care, maternal mortality, girls education beyond primary levels, vaccination etc.). 
Minded Group, 1990; Best, 2013), participatory approach (Lister, 2004), multidimensional poverty (OPHI, 2015; Alkire, 2007; Alkire and Santos, 2010), and Shame (Nicola Jo, 2013, Shildrick and MacDonald, 2013). Despite such variations in understanding what poverty is, a one-size-fit-all definition (applicable for all poor countries) is in operation since the inception of the MDGs and now in the SDGs. This section sketches out the problems of this conceptualisation to show how this undermines the noble intention of poverty eradication.

According to the World Bank (2008), in estimating poverty worldwide, same poverty line needs to be used which is expressed in a common unit across the countries. For this purpose of global aggregation and comparison, the Bank initially used reference lines set at $\$ 1$ and $\$ 2$ per day (more precisely $\$ 1.08$ and $\$ 2.15$ a day) which was later updated to $\$ 1.25$ a day for extreme poverty line ${ }^{3}$. Most people ${ }^{4}$, however, feel that it refers to the income/consumption of $\$ 1.25$ measured in international exchange value. But, the reality is, this conceptualisation is calculated in Purchasing Power Parity (PPP) 5 value. The schism between PPP and exchange values is so significant that unless it is mentioned every time the whole understanding can be immensely misleading ${ }^{6}$. The SDGs clearly does not mention this as can be seen in its first target (see section-1).

Pogge and Sengupta (2015) clarify that extreme poverty in the SDGs is being measured based on PPP value of 2000, even though such framing fails to capture many of the hardships that constitute extreme poverty in the real world (for example, child labour, chronic undernourishment, illiteracy, exposure to violence and lack of access to safe drinking water, shelter, sanitation, electricity, and essential medicines). Question is

${ }^{3}$ Retrieved from, www.worldbank.org/poverty (accessed on 29 May 2008). However, the same source acknowledges that the poverty line can be varied across time and place as it contains, 'a common method used to measure poverty based on income or consumption levels. A person is considered poor if his or her consumption or income levels fall below some minimum level necessary to meet basic needs. This minimum level is usually called a 'poverty line'. What is necessary to satisfy basic needs varies across time and societies. Therefore, the poverty line varies in time and place' (World Bank 2008).

${ }^{4}$ I have opted to use the term people as a broad category referring to academics, non-academics, politicians, policy-makers, researchers, NGO workers, activists, students, media personnel, celebrities and common members of the society.

${ }^{5}$ Purchasing Power Parity is an economic concept and is determined in terms of the number of units of a country's currency that are equivalent to a unit of the currency of a base country. The PPP doctrine suggests that, based on the PPP value of one exchange rate, an individual should be able to buy the same bundle of goods in any country, and the exchange rate between two countries over any period of time is determined by changes in the relative prices in these countries (Alba and Park 2003, Yunus 2000).

${ }^{6}$ For example, the World Bank (2012) states on its website that 'nearly 1.3 billion people remain below the extreme poverty line with an income of US $\$ 1.25$ or less a day. Close to 2.5 billion - more than one-third of the world's population - live on less than US $\$ 2$ a day' (http://www.worldbank.org/en/topic/poverty/overview accessed on 24 November 2012). Here the Bank itself offers an overview on global poverty without mentioning the measurement is based on PPP values. More examples can be cited such as Kakwani (2006) who writes for the UNDP '...the most frequent measure used internationally, the $\$ 1$ a day per person (or $\$ 2$ a day), is not in accordance with the capability approach to poverty...'. According to UNESCO (2012), '...the international standard of extreme poverty is set to the possession of less than $1 \$$ a day' http://www.unesco.org/new/en/social-and-humansciences/themes/international-migration/glossary/poverty/ accessed on 24 November 2012). Somavia (2003:1) writes for the ILO; 'virtually half the world lives on less than US\$2 a day. More than 1 billion people struggle on $\$ 1$ a day or less'. None of these authors indicate that these measurements are based on PPP values and one can easily assume that they are based on international exchange rates. 
why poverty needs to be measured in US dollars (instead of local currencies for further ease), more specifically in PPP value of it? This is a notoriously complex process and beyond the grasp of many stakeholders and actors involved in poverty reduction/eradication. Answers to this question is not semantic, but are rooted in the fact that policy choices are not only a matter of apparent convenience of statistics, but also deeply political (Fischer, 2010). The notion of extreme poverty, adopted in the SDGs, carries the legacy of past approaches towards poverty reduction dominated by the leading International Financial Institutions (IFIs) and major donors 7 . Over the years, the agenda for poverty reduction has been sanitised and politicised to make them consistent with the dominant paradigm of conventional development thinking. To illustrate, a US dollar based definition of poverty was adopted in the MDGs despite the objection of many developing countries suggesting that the concept is ill-defined ${ }^{8}$. As Vandemoortele (2011) describes that through some tautological statistics the promotion of a US dollar based notion of poverty was a key priority for multilateral and bilateral donors. The readiness to take the poverty estimates in US dollar terms is therefore not just statistical; it also clearly serves a non-statistical purpose. The aim of repeating the assertion that millions of people have been lifted out of poverty is to ensure that the MDGs and subsequent development agenda do not upset the prevailing development paradigm. Neither this undercuts a money-metric and/or donor centric view of development. These efforts have been quite successful - as the poverty debate has been dollarised while the poverty reduction/eradication discourse has been donorised.

My contention, however, is not to suggest that a US dollar based poverty understanding is essentially wrong. I intend to highlight that: i), there are some in-built inconsistencies (such as incompatibility of different base years) that keeps the threshold of extreme poverty very low excluding a lot of poor people who otherwise should be targeted in poverty eradication efforts, and ii) it creates a massive confusion for a number of actors engaged in poverty reduction who might otherwise think this is based

7 While it claims to have reassessed the MDG planning process through an inclusive global consultation approach, it has, however, reproduced some of the most problematic flaws in the MDG process. Intended outcomes are limited to those that have calculable properties, rather than a deeper and holistic understanding of poverty (Sexsmith and McMichael, 2015).

8 According to Vandemoortele (2011), the process of sanitising the MDGs started with the redefinition of human deprivation in money-metric terms. The world summits of the 1990s focused on the aspects of human well-being (i.e. literacy and nutrition, health and reproductive health, gender equality and access to safe water). Donor countries wanted to introduce a global target for poverty at 1995 social summit in Copenhagen but developing countries objected because they found the concept ill-defined. A year later, donor countries issued the International Development Goals (OECD/DAC, 1996) which included the target of halving poverty by 2015. In 2000, that target was included in the Millennium Declaration but with an important amendment: it explicitly defined poverty as living on less than a dollar per day. This was unique because the Declaration did not specify indicator for any other target (ibid: 9). In fact, the word 'poverty' was actually not mentioned in the Declaration, which reads: to halve, by the year 2015, the proportion of the world's people whose income is less than one dollar a day. The formulation of the original target was 'a reduction by one-half in the proportion of people living in extreme poverty by 2015' (OECD, 1996: 2). No mention was made of the poverty norm of $\$ 1$ per day.

9 A general perception of extreme poverty here refers to the level of poverty where someone's absolute basic needs will be met in a dignified manner (be it through income-consumption, work, social capital or else). Minimum basic needs should cover one person's food, shelter, primary health, clothing, and basic education. 
on exchange value. Below, I elucidate these points further and assess what implications it may have for eradicating extreme poverty by 2030.

There is a lively debate about the inappropriateness of the PPP concept and consequent problems in measuring global poverty based on this method (see Reddy and Pogge 2010; Ravallion, 2010). Reddy and Pogge (2010) argue that the dollar based understanding of poverty is fraught with difficulties because there cannot be one set of PPPs that is appropriate for all purposes. Rogoff (1996) notes that ultimately, there is no right PPP measure as the appropriate PPP depends on its application. To illustrate, Alba and Park (2003) explain that each time a PPP base year is abandoned, all previous estimates of the extent of poverty calculated via those PPPs must be discarded too. Meaning that different base years are not comparable (Reddy and Pogge, 2010) as can be seen from the revision of 1985 PPPs to the 1993 PPPs resulting in large changes in poverty head-count ratios at the regional level ${ }^{10}$. In fact, large changes can occur even for the same country using the same data (Deaton, 2011). In 1999, applying \$1 per day PPP 1985 data, the World Bank reported very similar poverty rates for Nigeria and Mauritania of $31.1 \%$ and $31.4 \%$ respectively. In 2000 , applying its method with the new PPP value of 1993, the Bank reported poverty rates for Nigeria and Mauritania of $70.2 \%$ and 3.8\% respectively. Depending on which PPP base year is used, Nigeria's poverty rate is either slightly lower or 18 times higher than Mauritania's (for more information on this calculation see Reddy and Pogge, 2010) ${ }^{11}$. In its further update, in October 2015, the World Bank has changed the global extreme poverty line to $\$ 1.90$ a day taking 2011 as a base year for new PPP value (World Bank, 2016). As discussed above the problems of different base years for PPP and in that context while the SDGs framework adopted 2005 PPP value as benchmark for measuring extreme poverty, it is not clear though how this problem will be addressed in eradicating extreme poverty all over the world by 2030 ? Will the target now be revised or the measure from $\$ 1.25$ PPP a day to new 'more accurate' data. No doubt this portrays a messy picture for global poverty and poverty eradication goal of the SDGs.

Another key limitation of this process is that extreme poverty is being set at an extremely low level. Most poor people in this measure do not seem to be able to obtain absolute minimum amount of goods required for basic living in different country/local contexts. To illustrate, according to UN data (2015), an amount of Bangladeshi Taka (BDT) 36.87 should have the same purchasing power in Bangladesh in 2012 as US \$1 in

10 A study in Latin America shows that national extreme poverty rates, using poverty lines based on calorific and demographic characteristics, may be twice as high as those based on \$1(PPP) a day line (operational at the time of the study). The \$1 (PPP) a day line estimated Brazil's extreme poverty at 5\%, while the Economic Commission for Latin America, using a calories-and-demography poverty line, estimates the rate at 14\% (ECLA 2001: 51). The PPP has become even more contentious recently as the international comparison program (which collects price data across countries) collated actual and detailed price data from 146 countries in December 2007 since 2003 and for the first time with China's participation. The result has thrown doubt across the dollar a day data for many countries as actual prices are greatly in divergence with existing PPP estimates. The net effect of using PPP dollar a day measure is a lot more poor people (Sumner and Tiwari, 2009: 21).

11 Nevertheless, Chen and Ravallion (2001) think Reddy and Pogge overstate this problem. They argue that the $\$ 1.08$ line using the 1993 PPP gave a very similar global poverty count to the old $\$ 1$ a day line at $1985 \mathrm{PPP}$ for the common reference year in the series, namely 1993 which was later revised again in 2008. 
the United States in the same year. This means that someone in Bangladesh will be considered as extreme poor whose income is less than BDT 46.08 per day ${ }^{12}$ (for $\$ 1.25$ PPP) for the year 2012. In a Bangladesh context what a per day income of BDT 46.08 means for a person in concrete terms for that year? In 2012, the price for one kilogram of coarse rice ${ }^{13}$ was about BDT $29^{14}$ (FAO, 2015). An adult person, as a basic minimum, needs 400 grams of rice a day. This would cost BDT 11.60. One person would also require items such as salt, cooking oil, onions, lentils, and at least some vegetables if not fish or meat/poultry. Fuel-wood or kerosene would be needed to cook food - people living in urban areas will have to pay for it while people in rural areas may not or would pay lower price subject to whether they use kerosene or twigs/fuel-wood or both. Anyone with some knowledge of living costs in Bangladesh would agree that remaining BDT 34.48 would not be sufficient for those items. This clearly highlights a major weakness of understanding extreme poverty in Bangladesh through \$1.25 PPP a day. Even beggars in this measure would not be counted as extreme poor as in most cases they would earn more than BDT 46.08 per day.

I have also convened a similar exercise with two of my colleagues from Nigeria and Ghana who found the idea as 'laughable' and 'intellectual assault' on poor (personal communication). Using the same UN source we found that \$1 PPP was equal to 134.21 Naira (NGN) in 2012. Meaning that, extreme poverty in Nigeria should be understood whose income is below NGN 167.76 a day (for $\$ 1.25$ PPP). If an adult needs 250 grams of Garri (staple food of Nigeria), s/he would have to pay NGN 100. One adult would also need palm oil, salt, onion, spice cubes, kerosene or fuel wood for preparing a basic meal - without adding any meat, fish or vegetable with Garri. With NGN 67.76 obtaining all those will be impossible. In Ghana, we found that \$1 PPP was equivalent to GHS 0.85 (Cedi) in 2012. Meaning that extreme poverty line there would be whose income is below GHS 1.06 a day (for $\$ 1.25$ PPP). Rice is staple food in Ghana and 400 grams of rice would cost GHS 0.98. So, it was quite obvious that oil, onion, spices, kerosene or fuel wood ${ }^{15}$, vegetable or fish/meat was unthinkable to buy from rest of 8 Pesewas. One further point to note here that people have to pay for water in Nigeria and Ghana. Obviously, no money would be left for other basic needs. In all cases (Bangladesh, Ghana, and Nigeria) rent, cloths, education, health are not included in this measure. Moreover, poor people may end up in paying different (often higher) prices than the non-poor for the goods they consume ${ }^{16}$. For example, Biru (1999) found that

12 http://data.un.org/Data.aspx?d=MDG\&f=seriesRowID:699 (accessed on 28 August 2015).

${ }_{13}^{13}$ am not using the price of better quality rice that a middle-class family would tend to buy.

${ }^{14}$ In practice, people in Bangladesh would argue that the price was a bit higher and varied in different locations. But, using data from FAO offers more credibility and hence I am using it for my discussion. FAO (2015) also notes that this price was 12\% lower in September 2011 indicating price fluctuates more frequently than available updates of PPP rates (for example, as of October 2015, no data for 2013, 2014 and 2015 are available).

15 Please note most of these ingredients cannot be purchased in a quantity that will be needed for daily consumption. Therefore, for ingredients such as salt, onion, kerosene we have used smallest unit available and then calculated how many times those can be used to have an idea about per day cost as outlined below.

16 As Pogge (2013) observes that the world numbers for chronic undernourishment show a trend that is not harmonious with the trend in income poverty and attributes this to food prices rising faster than 
lower income groups paid more for the same commodities in Zambia, and that the differences in the prices paid by the different income groups were greatest in the poorest regions. Ravallion (2010), one of the leading proponents of dollar based poverty understanding, also admits that the idea of basing PPPs on a fixed bundle of goods is problematic as people consume very different things in different countries reflecting in part the differences they face in relative prices. He states that it would be very surprising if any kind of consensus could be reached on what should be included in the single global bundle of goods, comparable to the consensus that has been established around the $\$ 1$ or $\$ 1.25$ a day (PPP) concept.

One further problem with $\$ 1.25$ (PPP) a day extreme poverty understanding is that it can immensely mislead public awareness despite the claim of it serves the purpose of global comparison and coherence. The $\$ 1.25$ (PPP) per day concept for extreme poverty may have intuitive appeal to a Western audience being asked to support aid. But, Saith (2006) argues that it has an encapsulating effect. This influences not just the agenda of poverty reduction, but also its day-to-day lexicon capturing the bureaucratic and organisational imagination and culture like a latent but persistent linguistic virus ${ }^{17}$. Conceptualising extreme poverty through $\$ 1.25$ a day formula may appear to be simple, catchy and popular (perhaps with good intentions of global aggregation, comparability and creating mass awareness). With sustained media exposure and campaigning, a section of developed economies (potentially a certain section of developing economies as well) have become familiarised with this. However, as stated above, most people tend to have incorrect awareness of it. Over the last ten years, I have asked my students and colleagues in several British and Bangladeshi universities about their perception of dollar based poverty understanding and found that almost everyone thought this was based on exchange value. Most of them were even unaware of the PPP concept (used in measuring extreme poverty) and mentioned that this seems too technical for effective advocacy. It is worth mentioning here that my colleagues and students came from multidisciplinary backgrounds such as sociology, anthropology, psychology, development studies, politics, international relations, history, philosophy, journalism and media studies. I have also discussed this issue with mid-level politicians and policy makers in Bangladesh whose knowledge was not very different from my colleagues and students in the academia. My concern can be put in other words like this: would understanding of extreme poverty and its elimination require specialist knowledge or should it be based on simple notions so that key stakeholders ranging from mothers to ministers can easily understand it and be part of actions against poverty.

inflation, which would especially affect the poor, who spend disproportionately on food. This could be, in part, because of from where the poor people buy goods (for example, in semi-peripheral and rural areas with potentially less competitive retail market structures), or because of the quantities in which they buy (typically smaller amount than the non-poor because of cash-in-hand, credit, and storage limitations), or because of who they are (socially marginal), which may permit adverse retail market discrimination against the poor, or monopolistic price discrimination segmenting the retail market according to consumer income.

17 This is evident that during the last decade, and especially after setting out the Millennium Development Goals (MDGs), poverty has become virtually synonymous with an individual's income of less than one US dollar a day applicable for all poor countries. Economist to politician, developmentalist to celebrities, policy makers to commoners, seem to cite this formula with some ease regardless of whether they understand it correctly. 
However defined, measured and explained extreme poverty is not a natural fact, but a social experience. It is not a characteristic of a certain group of people; it rather characterises of a particular situation in which people may find themselves at a given point in time (Green and Hulme, 2005; Bastiaensen; De Herdt and D'exelle 2005). Understanding extreme poverty through \$1.25 PPP a day seem quite unhelpful. The argument/reasoning of how much money a person need to buy a bundle of goods with $\$ 1.25$ (PPP) seems highly problematic despite the theoretical promises of estimating the capacity of buying the same bundle of goods needed for basic living. A universal measurement/definition of extreme poverty can be prejudiced, based on the interests of those who propose such a definition as various dynamics of poverty cannot be perceived through a common definition based on PPP value of US dollars.

The appropriateness of using primarily monetary aspects for global poverty eradication, as is done with the dollar based method, needs to be seriously questioned. Cammack (2004) describes the poverty line of $\$ 1.25$ (PPP) a day as 'global proletarianisation' with a reserve army of labour acting as a disciplinary force in this proletarianisation process. Dollarisation of poverty (Kamruzzaman, 2015) aims to exploit the most productive resource of the poor - their labour by setting a minimum daily wage of $\$ 1.25$ (PPP). Unwin (2007) argues that the focus on the US dollar as the key indicator of poverty is deeply problematic. Based on the current notion of extreme poverty (as outlined in the MDGs and SDGs), the easiest way to reduce poverty would be to devalue the dollar. More subtly, adoption of the US dollar as the key measure of parity provides an image that somehow the wider model of the US economy is the one that should be adhered to if poverty is to be eliminated. Moreover, even if it were possible to shift the income of everyone in the world above the $\$ 1.25$ (PPP) a day line, thereby eliminating extreme poverty, this would be an empty victory. Extreme poverty would still remain; it would just be a little less.

Bearing this in mind, the next section takes a critical look at international target setting for global poverty and gaps in achieving stated objectives. This sets out the context to anticipate the potential challenges for poverty eradication everywhere in next 15 years.

\section{Global Target Setting and Lack of Achievements towards Poverty Reduction}

Poverty reduction/eradication is not a serendipitous goal. Rather, this needs to be viewed in connection with past development initiatives such as the development decades of 1960-2000. To illustrate, the stated objective of the first development decade (1961-70) was to help low-income countries achieve development within a decade targeting 5 per cent annual GNP growth by 1970 (UN, 1961). The achievement was average annual GNP growth of 4 per cent in the 1970s. The second development decade (1971-80) was conceptually similar and targeted developing countries should grow annually at 6 per cent and each country should achieve 3.5 per cent annual per capita growth (UN, 1970). The achievement was GDP growth about 4.8 per cent per year. The third development decade (1981-90) targeted developing countries should achieve 7 per cent growth per year over the decade, and achieved average annual growth of 2.8 per cent (UN, 1980). One common focus of these decades was that they all deemed 
macroeconomic growth as key for poverty reduction. However, in the third decade, Koehler (2015: 738) observes, for the first time there was an explicit call for the eradication of poverty (article 7), hunger (article 93), and a commitment to food security (article 86). It also raised the issue of a 'fair distribution of benefits' (article 43). Unfazed by the lack of convincing progress in the past decades, in 1990, the UN adopted international development strategy for the fourth development decade (1991-2000). The objectives were to speed up the pace of economic growth in developing countries; devise a development process that meets social needs, reduces extreme poverty significantly, develop and use people's capacity and skills, and is environmentally sound and sustainable; improve the international systems of money, finance, and trade; strengthen and stabilize the world economy and establish sound macroeconomic management practices (UN, 1990). In sum, the four development decades were largely identical to each other, but poverty and the environment enjoyed increasing attention in their evolution. The idea and influence of development decades later withered as the efforts towards poverty reduction have been circling around the MDGs ${ }^{18}$. Clearly, for a long time, global development goals (particularly the poverty goals) have left significant gaps in setting targets and achieving those. This leads critics to argue that global poverty reduction initiatives have been insufficiently attentive to past failures (Sanderson, 2004; Saith, 2006). With the ground sounding target of eradicating extreme poverty everywhere by 2030 , it is not clear what would be potential safeguards to avoid the barriers those obstructed desired progress in the past. This will require a lot of poor countries to perform extremely well against their track records. To assess the challenges ahead in this journey let us revisit the claims of halving global poverty - what implications this might have on the goal of eradicating extreme poverty after the global number is claimed to have halved? Where do the majority of extreme poor people live? This will offer an appropriate background for forecasting what could be potential pitfalls for eradicating poverty by 2030 everywhere?

It is claimed that global poverty, in $\$ 1.25$ (PPP) measure, is being halved compared to the total number of world poor in 1990 (UN, 2014; UN 2013; World Bank, 2012; Poku and Whitman, 2011; Greenstein, Gentilini and Sumner, 2014). This is a great achievement in any standard. A number of scholars, however, argue that this was possible because of improvements in a few countries in Asia and Latin America while situation in Africa has not changed or improved much ${ }^{19}$ (Fukuda-Parr and Hulme, 2009;

18 In addition to four development decades, Koehler (2015) reminds us about two Poverty Eradication Decades (PED). He elucidates, the main objectives of these PEDs have been full employment and decent work for all and poverty eradication by 2017.The PEDs were more in line with the decade ideas and no longer had much influence on steering policies towards employment or social justice. There has been a growing disconnection between real-world policy decisions and development thinking in the UN. While gaining much aplomb in the political human rights sphere through the UN summits, the secretariat had become irrelevant for development policymaking. So the UN needed to recapture the ideational plane. It did this with the Millennium Declaration and the MDGs. Perhaps that is why these two decades are hardly being mentioned in the ongoing international development discourse.

19 A Development Initiatives (2015) study observes that much poverty reduction since 2000 has been concentrated in a few countries. According to the most recent year for which country-level estimates are available, just five countries account for over $85 \%$ of the reduction in the number of people living in extreme poverty between 2002 and 2011. In other words, what this (the claim to have halved the global 
Waage et. al., 2010; UN, 2014; UN, 2015c). What does the claim of halving poverty then actually means for most of the poor countries and what realistic picture it portrays for Goal-1/Target-1 of the SDGs? The following figure is adapted from the UN (2014) Millennium Development Goals Report showing the official achievement in global poverty reduction in between 1990 and 2010.

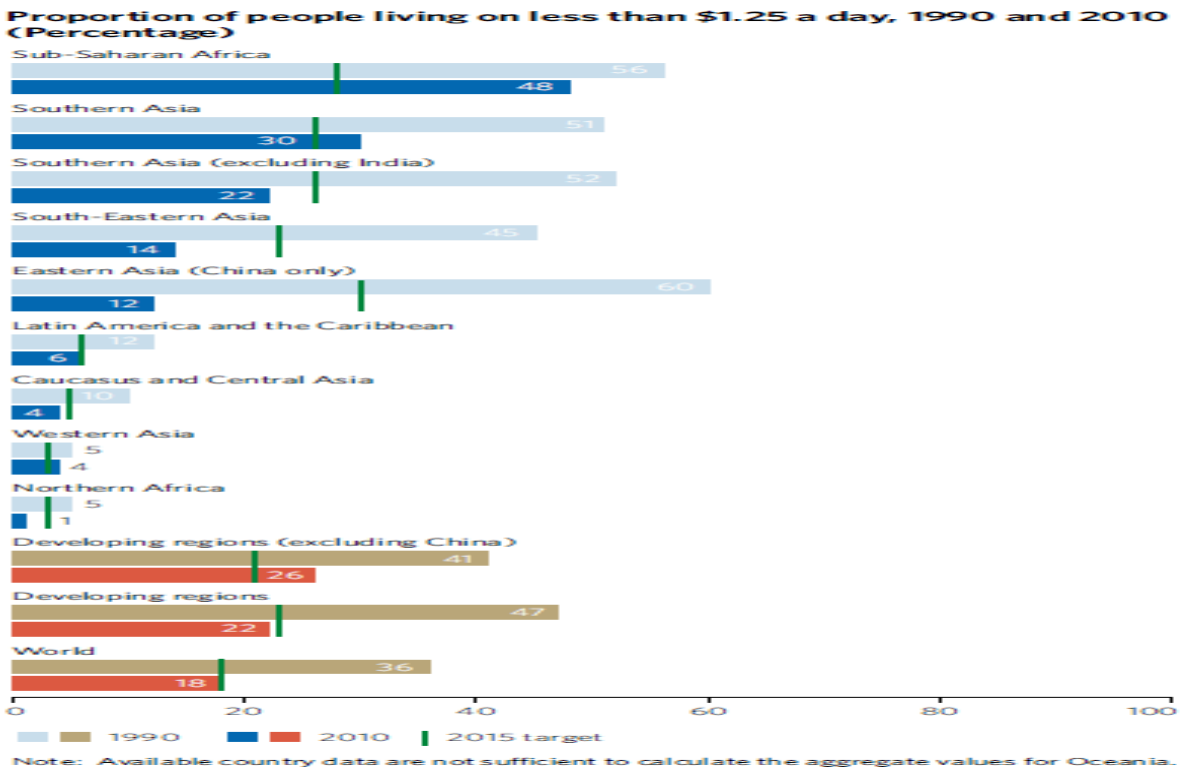

Figue-1: Proportion of people living on less than $\$ 1.25$ a day, $1990-2010$ (percentage), adapted from UN (2014:8)

The report reads: in 1990, almost half of the people in developing countries lived on less than $\$ 1.25$ a day. This rate dropped to 22 per cent by 2010 . The number of people living in extreme poverty fell from 1.9 billion in 1990 to 1.2 billion in 2010 (ibid: 9). This is worth noting here for a report of such high significance it was not mentioned that the measure was based on the PPP value - presenting another example of contradiction or misleading awareness of dollar based conceptualisation of extreme poverty. Perhaps, this forced the UN (2014a) to release a statistical annex for technical reasons and further clarification. The following table is adapted from that annex:

poverty) actually means is that the target of halving world poverty has been met largely due to China (Chen and Ravallion, 2012), or this can be seen as a by-products of the rapid growth of China and India (Chakravarty and Majumdar, 2008). Greenstein, Gentilini and Sumner (2014) offer a different reading, arguing that if China is removed from the world poverty data then the total number of people under $\$ 1.25$ (PPP) has barely changed since 1990 and the number of people under the \$2 (PPP) poverty line has risen slightly, which is increasingly recognised in official estimates by the World Bank who present the data with and without China. 
Goal 1 Eradicate extreme poverty and hunger ${ }^{20}$

Target 1.A: Halve, between 1990 and 2015, the proportion of people whose income is less than one dollar a day

Indicator 1.1: Proportion of population living below $\$ 1.25$ purchasing power parity (PPP) per daya ${ }^{a, b}$ (Percentage)

Table - 1: Proportion of people living on less than $\$ 1.25$ PPP per day. Adapted from UN (2014a, notes original)

\begin{tabular}{llllll}
\hline & 1990 & 1999 & 2005 & 2010 \\
\hline Developing regions & 46.7 & 36.5 & 26.9 & 22.0 \\
\hline Northern Africa & 5.2 & 5.0 & 2.6 & 1.4 \\
\hline Sub-Saharan Africa & 56.5 & 57.9 & 52.3 & 48.4 \\
\hline Latin America and the Caribbean & 12.2 & 11.9 & 8.7 & 5.5 \\
\hline Caribbean & 24.9 & 27.0 & 29.1 & 28.1 \\
\hline Latin America & 11.7 & 11.2 & 7.8 & 4.5 \\
\hline Eastern Asia & 60.2 & 35.6 & 16.3 & 11.6 \\
\hline Southern Asia & 51.5 & 43.1 & 37.7 & 29.7 \\
\hline Southern Asia excluding India & 52.0 & 36.3 & 29.3 & 21.5 \\
\hline South-Eastern Asia & 45.3 & 35.5 & 19.0 & 14.3 \\
\hline Western Asia & 5.1 & 5.0 & 4.6 & 3.6 \\
\hline Oceania & 42.0 & 34.4 & 43.1 & 35.0 \\
\hline Caucasus and Central Asia & 9.8 & 19.5 & 7.2 & 3.5 \\
\hline Least developed countries & 64.6 & 61.3 & 53.4 & 46.2 \\
\hline Landlocked developing countries & 53.2 & 52.2 & 40.9 & 33.0 \\
\hline Small island developing States & 29.6 & 29.5 & 32.0 & 29.4 \\
\hline
\end{tabular}

${ }^{a}$ High-income economies, as defined by the World Bank, are excluded.

${ }^{b}$ Estimates by the World Bank, April 2013.

Figure-1, and, Table-1 indicate that even though global poverty is claimed to have halved, but the number of poor people living in Sub-Saharan Africa, Southern Asia, least developed countries, landlocked developing countries, small island developing countries and the Caribbean was not halved. However, we need to remember that poverty reduction goal in the MDGs was not meant to be achieved by each poor country. If all countries were to halve their extreme poverty the world would exceed the target (see Vandemooretele, 2009). This represents possibly the most important difference between the poverty goal of the MDGs and SDGs. The SDGs have called for eradicating poverty everywhere.

Presumably, this time progress in some countries will not be sufficient and challenges to achieve this goal will obviously be different from that of the MDGs. In order to discern the challenges of this goal, let us explore where the majority of the

${ }^{20}$ It is interesting that the framing and language of the MDGs and SDGs are quite similar. Only difference is that MDGs Target 1.A was not coherent as it is not clear how halving the number of global extreme poor can mean 'Eradicating extreme poverty and hunger'. In the SDGs it aims to eradicate extreme poverty for all and everywhere. However, as stated before, the wording does not include the fact that this is aimed for people who is living less than $\$ 1.25$ based on PPP value. 
poorest people live in a post-2015 world. Even after global poverty is claimed to have halved since 1990, the world has now approximately 1.2 billion people who are living on less than $\$ 1.25$ (PPP) a day income. According to the UN (2014:9), they live in a handful of countries as shown in Figure-2. The overwhelming majority belong to two regions: namely, Southern Asia and Sub-Saharan Africa. In 2010, one third of the world's 1.2 billion extreme poor lived in India alone. China, despite much progress in poverty reduction, ranked second, and was home to about 13 per cent of the global extreme poor. Followed by Nigeria ( 9 per cent), Bangladesh ( 5 per cent) and the Democratic Republic of the Congo (5 per cent). Nearly two thirds of the extreme poor lived in those five countries in 2010. Aside from these populous countries with large numbers of the extreme poor, high poverty rates are often found in small, fragile and conflict-affected countries $^{21}$.

\section{Top five countries with the largest share of the global extreme poor, 2010 (Percentage)}

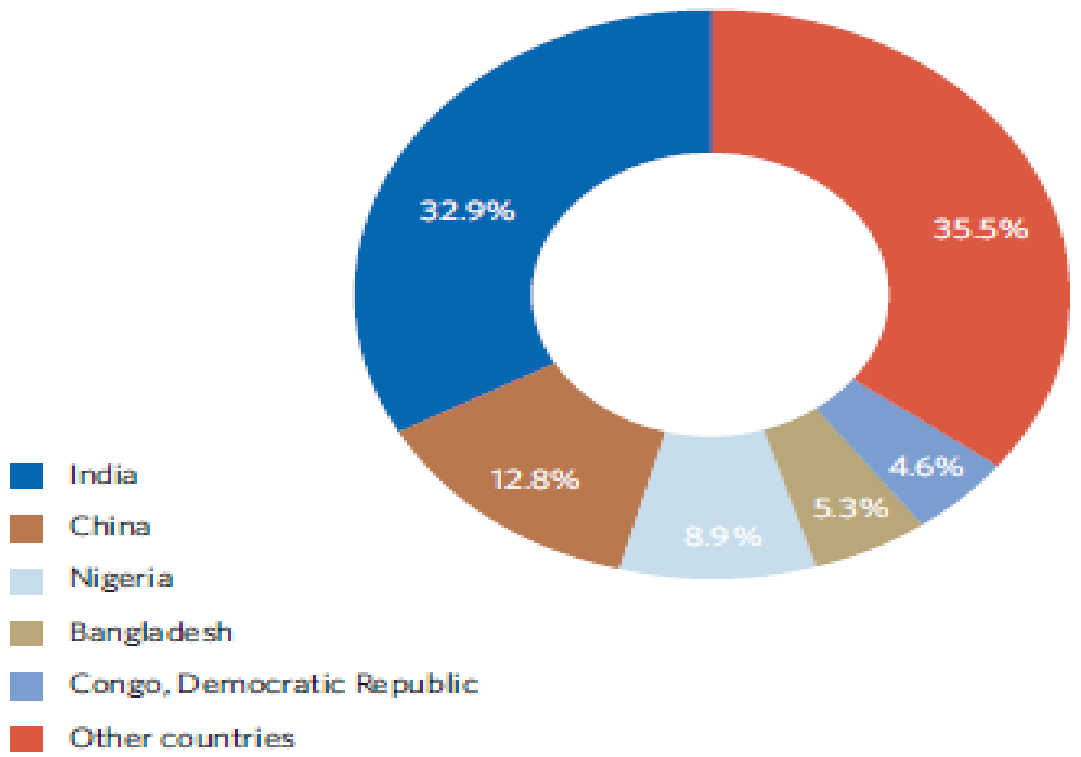

Figure - 2: Where do poor people live? (adapted from UN, 2014:9)

\section{Key challenges in eradicating extreme poverty everywhere by 2030}

Based on above discussion, in this section, I identify a number of key challenges for eradicating extreme poverty everywhere by $2030^{22}$. Clearly, a lot of countries did not do

21 The MDGs report (UN, 2014: 12-13) also asserts that a total of 842 million people, or about one in eight people in the world, were estimated to be suffering from chronic hunger in 2011-2013. The vast majority of these people (827 million) resided in developing regions.

22 This must be noted here that I have not included environmental challenges here. Global warming and climate change and its impact on poor people in many developing countries will certainly play an important role in achieving/missing the target of eradicating extreme poverty everywhere by 2030 . As 
well during the development decades and the MDGs timescale (section-3). A first challenge will be that these countries will have to perform a magic in terms of poverty reduction in next 15 years against their past records. Second, the world needs to be consistently peaceful so that war, conflict, and violence do not affect poverty eradication efforts, particularly within the politically fragile countries where a large number of extreme poor live (see below). Third, there needs to be apposite mechanism for reform in the global monetary system so that in the unlikely events of financial crises in the Western economies (such as the one in 2008) aid assistance for poor countries will not be affected and global poor will not pay the price in various other ways. The fourth challenge would entail improving low-quality, and limited international comparability of data on poverty eradication in most developing countries. Finally, the fifth challenge would be minimising uncertainty about the sources of investment that will be required for poverty eradication. Below, I briefly expand on these challenges.

The first challenge applies for those countries to make unprecedented progress whose track record for poverty reduction in recent years are not very encouraging. According to the UN (2015d), each country faces specific challenges in pursuit of poverty reduction. This is particularly true for the most vulnerable countries, such as, African countries, least developed countries, landlocked developing countries and small island developing states, and countries in situations of conflict and post-conflict. Let us assess what these countries will have to do to eradicate extreme poverty by 2030. Based on PovcalNet and the World Bank data, a Development Initiative report (2015) suggests that to end extreme poverty by 2030, a lot of these countries must reduce poverty rapidly. For many countries this would require a significant change from their current trajectory. Sub-Saharan Africa (SSA) ${ }^{23}$ faces the greatest challenge (see Figure-3) - from experiencing a small rise in the number of people in extreme poverty during the MDGs period, to realising a pace of poverty reduction faster than the rate achieved by South Asia in last 15 years. A number of countries would require both reversal of current trends and rapid acceleration of progress. On current trends East Asia is set to end extreme poverty before 2030, and South Asia needs to maintain a similar pace to that achieved under the MDGs.

much as I am aware of this fact, I also feel that this issue is beyond the remit of this paper and I hope to address this in latter works.

${ }_{23} \mathrm{SSA}$ is home to 32 of the 33 countries with the greatest depth of poverty and has seen the slowest progress in reducing poverty during MDGs timescale. 


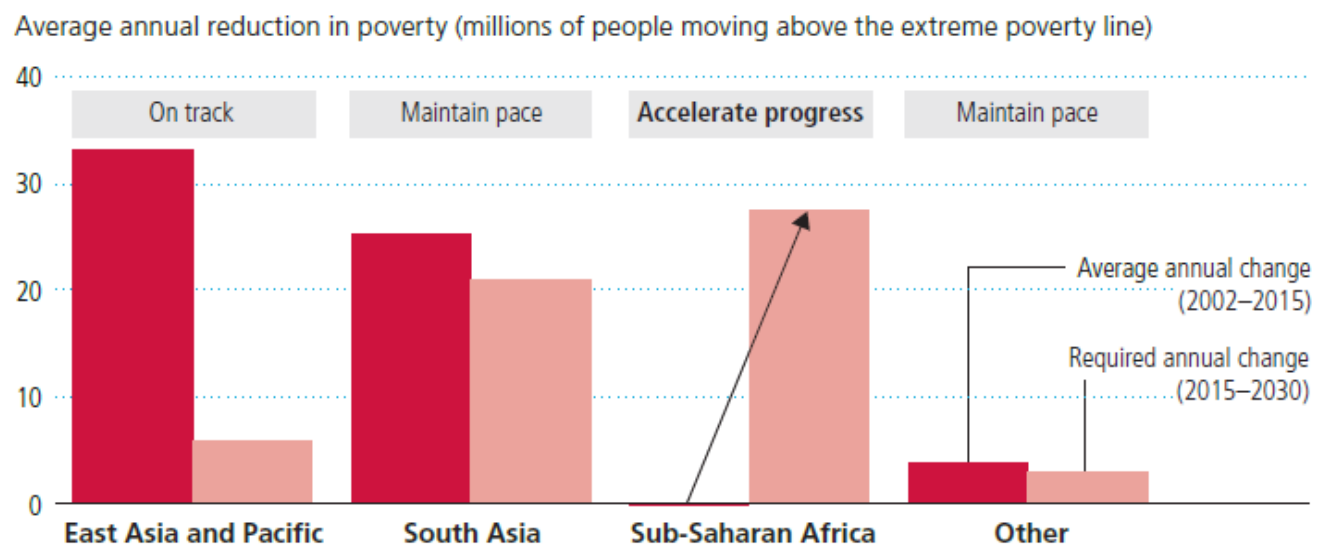

Notes: The left hand columns show the number of people lifted out of poverty on average annually in each region between 2002 and 2015; the right hand columns show how many people currently living in poverty must be lifted out of poverty on average each year between 2015 and 2030 if each region is to meet the target of zero extreme poverty in $2030 .^{9}$

Source: Development Initiatives calculations based on PovcalNet and World Bank Figure-3: What Needs to be Done to Eradicate Extreme Poverty by 2030. Aadapted from (Development Initiatives 2015:11, notes original)

Scott and Lucci (2015) argue that if the Low-Income countries (LICs) (among the 75 countries of their study $)^{24}$ are to fulfil the global target of eradicating extreme poverty by 2030 , they would require annual reductions of 3.35 percentage points over the next 20 years (as of 2010 estimates). By way of comparison, China achieved yearly reductions of 2.5 percentage points between 1990 and 2010. This will indeed be a miracle if these countries can accomplish this. Even the countries who have done well, not only need to maintain their pace but also should ensure that it takes place evenly across the whole country. As Development Initiative (2015) study observes that national trends in poverty reduction mask big differences within countries. For example, between 2005 and 2012, poverty was reduced 10 percent a year in ten states in India while poverty actually rose in eight other states.

Another challenge to eradicate extreme poverty everywhere would be the aspect of securing sustained peace in contrast to the world we are living in today. The UN (2015d) insists that along with rising inequalities (in terms of wealth and power), gender inequality, unemployment, global health threats, more frequent and intense natural disasters (which are also mentioned as key factors for poverty and spiralling conflict), violent extremism, terrorism and related humanitarian crises and forced displacement threaten to reverse much of the development progress. There are clear interlinks of these

${ }^{24}$ Their study incorporated 17 low-income (LICs), 37 middle-income (MICs) and 21 high-income countries (HICs), using the World Bank classifications. They claim that this sample represents a regional balance as 19 European countries, 21 African countries, 11 Latin American, 2 North American and 21 countries from Asia and the Pacific were selected representing 85 per cent of the world's population, 85 per cent of the world's GDP, 85 per cent of the population currently (2010) living in poverty and 85 per cent of global greenhouse gas emissions (Scott and Lucci, 2015: 755). 
aspects with extreme poverty as can be observed in Figure-4 that vast majority of the poor people live in politically fragile countries (Development Initiatives, 2015).

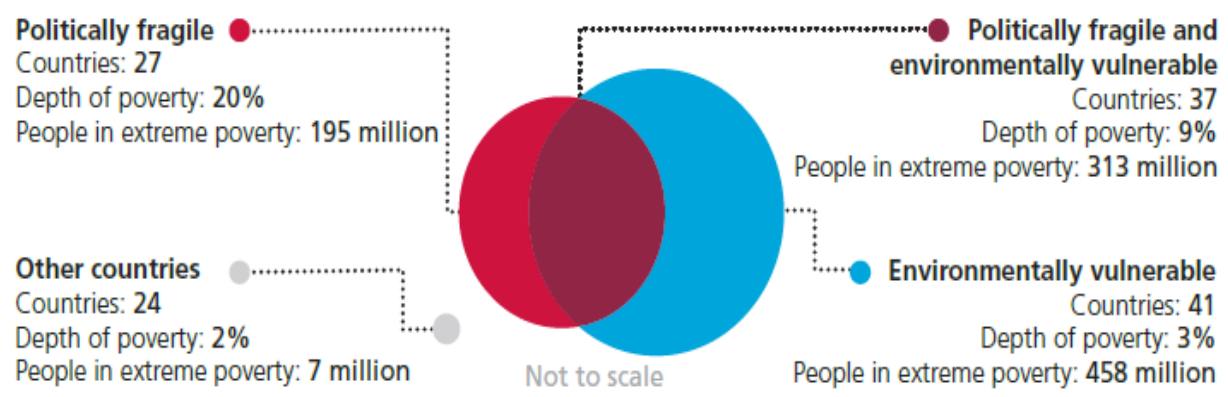

Notes: circles are representative of the number of people living in extreme poverty in countries in each group. Fragile states are defined based on the Fragile States Index 2015. ${ }^{11}$ Environmentally vulnerable countries are defined based on INFORM 2015 mid-year update. ${ }^{12}$

Source: Development Initiatives calculations based on World Bank PovcalNet, Fund for Peace and Information for Risk Management

Figure-4: People living in extreme poverty in politically fragile and environmentally vulnerable countries. Adapted from Development Initiatives (2015:11, notes original)

According to the UN (2014:15), the number of newly displaced persons has tripled since 2010. The year 2013 was marked by multiple refugee crises with 51 million people were displaced forcibly worldwide as a result of persecution, conflict, generalised violence and human rights violations ${ }^{25}$. The challenge would be to motivate the governments of these countries to fully engage in poverty eradication efforts who may have other political agenda (be it racial, ethnic, conflictual, and religious) ${ }^{26}$. For Tomlinson (2015), peace issues are central to the elimination of extreme poverty, and this is particularly the case in the most challenging environments where the most intractable poverty lies. The effort to eliminate extreme poverty must tackle the issues of fragile and conflict-affected societies - where the MDGs-based approaches have failed. Even though, the UN Task Team (UNT'T) on post-development agenda (UNTT, 2012) identified peace and security as critical for development the SDGs do not seem to put adequate reflection on peace and security. The UN (2015d) statement: 'we are determined to foster peaceful, just and inclusive societies which are free from fear and violence. There can be no sustainable

25 This raises the question would these people be included in the headcount of extreme poverty whose income is less than $\$ 1.25$ (PPP) a day. If yes, how? Without a clear steer set in place poverty will not be eradicated everywhere.

${ }^{26}$ For example, under current situation of the world some countries such as Syria, Iraq, Yemen, Myanmar, Bangladesh, Afghanistan, Palestine, and Libya are going through war or serious violent conflicts. Would the governments concentrate on the more pressing problems such as war, refugee, political turmoil, fighting terrorism - or these countries will shift their focus solely on eradicating poverty? As the SDGs aim to eradicate extreme poverty everywhere - these are some places that are unlikely to join the fight in their fullest capacities or with the level of commitment that would be required to achieve this target. 
development without peace and no peace without sustainable development' - seems rather vague and rhetorical as these are not concrete strategies to stop war/conflict and secure peace.

The third challenge to eradicate extreme poverty everywhere lies within the current global economic structure. Present economic world order is unfair to the developing countries and contributing in perpetuating poverty. A major issue with current economic structure is its failure to stop illicit money flows. Biron (2013), for example, reports that developing countries lose $\$ 1$ trillion a year in illicit financial flows arising from crime, corruption and tax havens used by multi-national corporations to avoid tax liabilities. To be more specific, the developing countries have lost over $\$ 634$ billion dollars through illicit financial flows in 2011 and \$486 billion in 2012 through profits repatriated by international investors (Griffiths, 2014). Tax treaties is another issue where the world is suffering by the biggest corporate industries. Developing countries are being affected severely where companies invest in most developing countries through secret jurisdictions which gives them the privilege of virtually tax free business (James, 2012). Recent revelations of so-called Panama Papers of Mossack Fonseca is an expedient example of such trend. This represents a major loss of revenue for developing countries, approximately ten times the amount of foreign aid these countries are receiving ${ }^{27}$. Eradicating extreme poverty would require to address the structural deficits of the current world order that can easily destabilise developing societies. The SDGs make some mention of illicit money flows and transnational crime, but are largely silent on addressing the impact of the economic policies of the key actors in this regard. To illustrate, the UN (2015d) calls for 'further effective measures and actions to be taken, in conformity with international law, to remove the obstacles to the full realization of the right of self-determination of peoples living under colonial and foreign occupation' - but these appear to be rhetorical and do not seem to be capable of making meaningful change in this regard. The logic of simplicity, concreteness, and quantification (such as understanding extreme poverty through \$1.25 PPP a day) will tend to squeeze out issues such as stabilising financial markets and strengthening regulation for money laundering/illicit financial flows, debt, unfair trade rules and corporate power (FukudaParr and McNeill, 2015; McCloskey, 2015). In its current format, poverty eradication target in the SDGs neglect inequality among the countries, imposing a one-size-fits-all targets for most developing countries those are very different from each other (in terms of their current state of poverty, natural resources and geo-political contexts). Addressing these issues will require to go beyond just re-writing goals and targets that adhere to sustaining the same old economic and social models (Moore, 2015) and would need to recognise the causes of poverty rooted in unequal power structures within and between countries.

Fourthly, the validity of high quality internationally comparable data on poverty will also be a great challenge for post-2015 poverty agenda. As the UN (2015d) rightly observes that baseline data for several of the new development targets (in SDGs) remain

27 To illustrate, in 2014 the total amount of Official Development Assistance was $\$ 134.38$ billion, for 2013 it was $\$ 135.07$ billion, for $2012 \$ 127.62$ billion, for 2011 , $\$ 132.39$ billion, for 2010 , $\$ 134.77$ billion and for 2009, $\$ 127.24$ billion. (OECD, 2015). 
unavailable, and increased support for strengthening data collection and capacity building in member states are of immense significance to develop national and global baselines where they do not yet exist. The absence of necessary data and information for many indicators of the MDGs has affected transparency, accountability, and effectiveness of delivering development. Bhattacharya (et al.) (2014), therefore, assume that a data revolution would be key to improve the accountability of the next set of goals. The question is what will be the effective way ahead to improve data quality. The paradox is many developing countries may not have required resources and technical knack for this. Many countries manipulate statistics to meet donor criteria in order to get external grant (Kamruzzaman, 2015). This leads us to suspect that the planned framework of the United Nations may actually contradict with the notion of country ownership and continue to donorise poverty agenda ${ }^{28}$. Poverty eradication needs to be fair in what it requires of national governments, taking account of different country conditions, capacities and capabilities. Otherwise, there is a risk that this may end up being either too ambitious, or not ambitious enough (Scott and Lucci, 2015). Different countries use different indicators to measure progress towards the same target. This makes crosscountry comparison very difficult and in many cases impossible. Moreover, there are concerns that many regimes want to control the information given to the public and to international agencies for their own benefit (Camacho, 2015). If this persists, eradicating poverty will be a propaganda; with little or no meaningful progress.

The fifth challenge would be minimising uncertainty of required investment for poverty eradication in developing countries ${ }^{29}$. The UN $(2015 \mathrm{e})$ observes that with the right financing it is possible to end extreme poverty by 2030. There are various estimates in terms of the amount required. For example, infrastructure in developing countries (such as water, agriculture, telecoms, power, transport, buildings, industrial and forestry sectors) would require $\$ 5$ to $\$ 7$ trillion globally to meet all goals of the SDGs. UNCTAD has also estimated that the total investment needed in developing countries amounts to \$3.3-4.5 trillion annually, with current investment at \$1.4 trillion implying an investment gap of \$1.9-3.1 trillion per year (ibid). More specifically, to end extreme poverty and hunger by 2030 , it is estimated that it would require an additional US $\$ 267$ billion annual investment (FAO, IFAD and WFP, 2015). Finding additional $\$ 267$ billion (a 200 percent rise of current annual ODA, and approximately one quarter of the amount poor

${ }^{28}$ As it is outlined in UN (2015c; 2015d) that the global indicator framework, to be developed by the Inter Agency and Expert Group on SDG Indicators, will be agreed by the UN Statistical Commission by March 2016 and adopted thereafter by the Economic and Social Council and the General Assembly, in line with existing mandates. It is suggested that this framework will be simple yet robust, address all SDGs and targets including for means of implementation, and preserve the political balance, integration and ambition contained therein. The report insists that this will promote transparent and accountable scaling-up of appropriate public-private cooperation to exploit the contribution to be made by a wide range of data, including earth observation and geo-spatial information, while ensuring national ownership in supporting and tracking progress.

29 According to Bhattacharya and Ali (2014), there is consensus about three major areas circumscribing the scope of the financial means of implementation for SDGs and poverty eradication. Such as, official development assistance (ODA) and debt relief will continue to be important inputs for the delivery of the post-2015 international development agenda. Developing countries need to mobilise more resources from various sources too. 
countries lose due to illicit flows of money) for poverty eradication will be a big obstacle. As in the last round of global poverty reduction additional funding was not found even though a number of scholars indicated it would require a lot less than $\$ 267$ billion for poverty goals and/or all aspects of MDGs as shown in Table-2.

Table-2: Estimated additional deemed to be required to achieve Poverty and other goals of MDGs (based on Clemens, Kenny and Moss, 2007:737)

\begin{tabular}{l|l|l}
\hline Study & Covering & Annual new Money \\
\hline Zedillo et al. (2001) & Global, MDGs & $\$ 50$ billion \\
\hline African Development Bank (2002) & 30 African countries, MDGs & $\$ 20-25$ billion \\
\hline Devarajan et al. (2002) & Global, poverty goal & $\$ 54-62$ billion \\
\hline Greenhill (2002) & Global, poverty goal & $\begin{array}{l}\$ 15-46 \text { billion, }+100 \% \\
\text { debt cancellation }\end{array}$ \\
\hline Mingat et al. (2002) & $\begin{array}{l}\text { 33 African countries, primary } \\
\text { education }\end{array}$ & $\$ 1$ billion \\
\hline Oxfam (2002) & Global, MDGs & $\$ 50-80$ billion \\
\hline Vandemoortele (2002) & Global, MDGs & $\$ 73$ billion in 2006, \\
\hline UN Millennium Project (2005) & Global, MDGs & $\$ 135$ billion by 2015 \\
\hline
\end{tabular}

\section{Conclusion}

It is true global targets such as the MDGs have galvanised more awareness among many stakeholders than during the development decades of the 1960s, 1970s and human right treaties in the 1990s. Thus, Vandemoortele (2014) insists that most stakeholders wanted a successor arrangement beyond 2015. The goodwill is clearly visible in the $\mathrm{SDG}^{30}$. But, Amin (2006) notes that development goals on poverty reduction is nothing but an empty incantation as long as the policies that generate poverty are not analysed, denounced and alternatives are not proposed. Weber (2015) concurs with this view and asserts that the implications are far more pernicious.

Poverty eradication everywhere is a noble intention but may appear to be lipservice for several reasons. First, like many other popular poverty rhetoric, Target1/Goal-1 of the SDGs aim big: to eradicate extreme poverty everywhere by 2030. A major drawback for global anti-poverty programme is that the aid architecture fails to address

30 As the UN (2015d) reports; we are resolved to free the human race from the tyranny of poverty and want and to heal and secure our planet. As we embark on this collective journey, we pledge that no one will be left behind. The 17 Sustainable Development Goals and 169 targets which we are announcing today demonstrate the scale and ambition of this new universal Agenda. They are integrated and indivisible and balance the three dimensions of sustainable development: the economic, social and environmental. The Goals and targets will stimulate action over the next fifteen years in areas of critical importance for humanity and the planet. 
the structural constraints poor countries are facing, and unable to tackle power imbalances within the global economic system that limit the scope for poor countries to promote prosperity and well-being of their people (Fukuda-Parr and McNeill, 2015). This leads to the question whether such grand frameworks have enough political commitment for poverty eradication. Because, ultimately this demands strong political commitment from global political leaders, (inter)national civil society, development workers and activist (Kamruzzaman, 2014; Bhattacharya and Ali, 2014) in contrast to good intentions of leaving no one behind. If there is no strong political commitment and desire to go beyond the existing models where structural issues of (extreme)poverty are being addressed (including the roles of donor conditionalities, the debt burden, illicit money flow, tax avoidance by the large multi-national corporations, arms trade and their effects on continued war and conflict, global warming and climate change, income and wealth inequality, gender inequality, international fundamentalism and terrorism) there is a real risk that the SDGs could join other UN resolutions those are full of goodwill but with little practical relevance.

Second, by focusing heavily on income poverty it ignores many important aspects of poverty and excludes a great number of people who otherwise should be targeted in global fight against extreme poverty. This also extend the confusion. The notion how extreme poverty is defined is problematic and its universal application seem to have strong limitations (see section-2). As much as eradicating extreme poverty everywhere is a bold target in itself, it is not plausible how the countries, those have not been able to lift reasonable amount of people out of poverty in last few decades, will be able to eradicate poverty in next fifteen years. The propositions of increased aid, new infrastructure, creating employment for everyone have been repeatedly incorporated in a plethora of global treaties ${ }^{31}$. Their under-achievements make them more of a demagogy than concrete plans for poverty eradication with genuine political commitments. The SDGs rightly point out that stable societies (and peace) are fundamental for poverty

31 This is manifested in UN's own statement, as the UN (2015a) explains: it [the SDGs] reaffirmed the commitment to fully implement the Rio Declaration, Agenda 21, the Programme for the Further Implementation of Agenda 21, the Plan of Implementation of the World Summit on Sustainable Development (Johannesburg Plan of Implementation) and the Johannesburg Declaration on Sustainable Development, the Programme of Action for the Sustainable Development of Small Island Developing States (Barbados Programme of Action) and the Mauritius Strategy for the Further Implementation of the Programme of Action for the Sustainable Development of Small Island Developing States. It also reaffirmed the commitment to the full implementation of the Programme of Action for the Least Developed Countries for the Decade 2011 - 2020 (Istanbul Programme of Action), the Almaty Programme of Action: Addressing the Special Needs of Landlocked Developing Countries within a New Global Framework for Transit Transport Cooperation for Landlocked and Transit Developing Countries, the political declaration on Africa's development needs and the New Partnership for Africa's Development. It reaffirmed the commitments in the outcomes of all the major United Nations conferences and summits in the economic, social and environmental fields, including the United Nations Millennium Declaration, the 2005 World Summit Outcome, the Monterrey Consensus of the International Conference on Financing for Development, the Doha Declaration on Financing for Development, the outcome document of the Highlevel Plenary Meeting of the General Assembly on the Millennium Development Goals, the Programme of Action of the International Conference on Population and Development, the key actions for the further implementation of the Programme of Action of the International Conference on Population and Development and the Beijing Declaration and Platform for Action, and the outcome documents of their review conferences. 
eradication (UN, 2015d). But, there is no concrete plan for peace and improved security. Moreover, dollar-based notion of extreme poverty is far from adequate to understand poverty as a consequence of war, conflict, and disaster. At the time of writing this paper, Syria along with other parts of the Middle-East is going through serious civil conflicts if not full-fledged war. There are ongoing tensions in many African countries, and in South Asia to say the least. That is the Achilles hill in eradicating poverty everywhere as war/conflicts do not seem to be stopping quite soon.

Third, like previous poverty reduction/eradication endeavours, this time too growth has been prioritised over other social, political and structural components of poverty. Nevertheless, intended growth to eradicate income based extreme poverty will demand a massive boost in investment. It is not clear, however, who will make these investments and whether these will be philanthropic or pro-profit ventures. The latter might make poor people poorer. Furthermore, growth and other poverty eradication efforts might get affected due to the drawbacks of global financial systems. Unfettered trade liberalisation and excessive deregulation have led to global economic crises in 2008 and destroyed economic and social development in many societies ranging from the Organisation for Economic Co-operation and Development (OECD) countries to the least developed countries (Yiu and Saner, 2014). As a consequence, McCloskey (2015) argues, many countries that have struggled to reach the forty-five year old target of 0.7 percent of their GNI for overseas aid, a massive ransom was found to bailout the failing banks. In Britain, $f_{1} 1,162 \mathrm{bn}$ was provided in support to UK banks in the immediate aftermath of the crisis $(\mathrm{NAO}, 2012)$ while a comparatively paltry sum of $f^{8} 8.62 \mathrm{bn}$ was provided in official development assistance in 2011 (DfID, 2013). There is no concrete plan how in the event of similar incidents poor countries will not be affected in terms of their efforts in achieving growth, and other social developments those might be dependent on donor assistance.

By 2030, world population will grow from 6.8 to 8.3 billion (Gore, 2015). How many of increased population will contribute to the global number of extreme poverty and how that can be prevented (in order to eradicate extreme poverty) need to be thought out carefully and critically. Poverty eradication at the national and global levels should be devised with great humility and honesty bearing in mind that none of the past attempts managed to achieve the set objectives. Honest reflections will require why it did not happen and what could happen for the next round of global anti-poverty battle. Strong political will to look beyond the existing model(s) will come from such reflexive exercises. The series of international targets for poverty reduction maybe seen as an indication of a dangerous proliferation of words in substitution for actions. One might argue that one document follows another in a pattern that actions do not seem to follow (Camacho, 2015). To eradicate poverty, the world needs to overcome socio-political obstacles such as war/conflict, unfair global economic structure, terrorism and other root causes that create and perpetuate extreme poverty. At the same time, some technical issues such as current conceptualisation of extreme poverty; data availability, its validity and international comparability will have to be revisited too. Failure to do so might just prove some critics right - as Pogge and Sengupta (2015) forecast that like their predecessors, the SDGs will be a statement of aspirations. 


\section{References}

Alba, J. D. and Park, D. (2003), 'Purchasing Power Parity in Developing Countries: Multi-Period Evidence Under the Current Float', World Development, Vol. 31, No. 12, pp. 2049 - 2060

Alkire, S. (2007), 'Choosing dimensions: the capability approach and multidimensional poverty' in Kakwani, N. and Silber, J. (Eds), The Many Dimensions of Poverty, New York: Palgrave Macmillan

Alkire, S., and Santos, M. E. (2010), Acute Multidimensional Poverty: A New Index for Developing Countries, OPHI Working Paper 38, Oxford Poverty \& Human Development Initiative (OPHI), University of Oxford

Amin, S. (2006), 'The millennium development goals - A critique from the south', Monthly Review, Vol. 57, No. 10 , pp. $1-15$

Atkinson, A.B. (1998), 'Social exclusion, poverty and unemployment' in A.B. Atkinson and J. Hills (Eds), Exclusion, Employment and Opportunity, CASE Paper 4, London School of Economics, pp. 1-21

Bastiaensen, J., De Herdt, T. and D'exelle, B. (2005), 'Poverty Reduction as a Local Institutional Process', World Development, Vol. 33, No. 6, pp. 979 - 993

Baulch, B. and Hoddinott, J. (2000), 'Economic mobility and poverty dynamics in developing countries', Introduction to special issue of Journal of Development Studies, Vol. 36, No. 6, pp. 1 - 24

Best, J. (2013), 'Redefining Poverty as Risk and Vulnerability: shifting strategies of liberal economic governance', Third World Quarterly, Vol. 34, No.1, pp. 109-129

Bhattacharya, D. and Ali, M. A. (2014), 'The SDGs - What are the "Means of Implementation"?', Future United Nations Development System, Briefing 21

Bhattacharya, D., Islam, T., and Salma, U. (2014), 'A commentary on the final outcome document of the Open Working Group on SDGs', SAIS Review of International Affairs, Volume 34, Number 2, pp. $165-177$

Biron, C. (2013) 'Developing countries lose \$1 tn a year from 'illicit financial flows', The Guardian, 13 December 2013, retrieved from http://www.theguardian.com/globaldevelopment/2013/dec/13/developing-countries-illicitfinancial-flows (accessed 31 August 2015)

Biru, Y. (1999). 'The Purchasing Power of the Poor: A Case Study of Zambia' in F.G. Pyatt and M. Ward (eds), Identifying the Poor, Amsterdam: IOS Press

Camacho, L., (2015), 'Sustainable Development Goals: kinds, connections and expectations', Journal of Global Ethics, Vol. 11, No.1, pp. 18-23

Cammack, P. (2004), 'What the World Bank Means by Poverty Reduction, and Why it Matters', New Political Economy, Vol. 9, No. 2, pp. $189-211$

Chakravarty, S. R. and A. Majumdar (2008) 'Millennium Development Goals: measuring progress towards their achievement', Journal of Human Development, Vol 9, No. 1, pp. 109-29

Chen, S., and Ravallion, M. (2012), More Relatively Poor People in a Less Absolutely Poor World, Policy Research Working Paper, Washington, D.C.: World Bank Development Research Group

Chen, S. and Ravallion, M. (2001), 'How Did the World's Poor fare in the 1990s?', Review of Income and Wealth, Vol. 47, No. 3, pp. $283-300$

Clemens, M. A., Kenny, C. J. and Moss, T.J. (2007), 'The Trouble with the MDGs: Confronting Expectations of Aid and Development Success', World Development, Vol. 35, No. 5, pp. 735-751

Copenhagen Consensus Center (2015), Post-2015 Consensus What are the smartest targets for the post-2015 development agenda? [Online] http://www.copenhagenconsensus.com/post-2015consensus?gclid=CJvn6 W'Tq8gCFUFQ2wodalYNIg accessed on 4 October 2015)

Dandekar, V. M. (1981), 'On Measurement of Poverty', Economic and Political Weekly, Vol. XVI, No. 30, pp. $1241-1250$

Deaton, A. (2011), 'Measuring Development: Different Data, Different Conclusions?' in Measure for Measure How Well Do We Measure Development?, Proceedings of the 8th AFD-EUDN Conference, Paris

Department for International Development (DfID) (2013), 'Statistics at DfID', retrieved from https://www.gov.uk/government/uploads/system/uploads/attachment_data/file/142459/SID_ 2012-Key-Statistics.pdf (accessed 6 June 2013).

Development Initiatives (2015), Investments to End Poverty 2015, Bristol: Development Initiatives

Economic Commission for Latina America (ECLA), (2001), Panorama social de America Latina 2000-01, ECLA (CEPA L), Santiago 
Food and Agriculture Organization of the United Nations (FAO) 2015, Price Monitoring and Analysis Country Brief: Bangladesh, retrieved from http://www.fao.org/docrep/015/an606e/an606e00.pdf (accessed on 28 March 2015)

Food and Agriculture Organization (FAO), International Fund for Agricultural Development (IFAD), and World Food Programme (WFP) (2015), Acbieving Zero Hunger: the critical role of investments in social protection and agriculture, ROME: FAO

Fukuda-Parr, S. and Hulme, D. (2009), International Norm Dynamics and 'the End of Poverty': Understanding the Millennium Development Goals (MDGs), BWPI Working Paper 96, Brooks World Poverty Institute, University of Manchester

Fukuda-Parr, S. and McNeill, D. (2015), 'Post 2015: a new era of accountability?', Journal of Global Ethics, Vol 11 , No, 1, pp. 10-17

Gore, C. (2015), 'The post-2015 moment: towards Sustainable development goals And a new global development Paradigm', Journal of International Development, Vol. 27, No. 6, pp. 717-732

Green, M. and Hulme, D. (2005), 'From Correlates and Characteristics to Causes: Thinking About Poverty from a Chronic Poverty Perspective', World Development, Vol. 33, No. 6, pp. 867 - 879

Greenstein, J., Gentilini, U. and Sumner, A. (2014), 'National or International Poverty Lines or Both? Setting Goals for Income Poverty after 2015', Journal of Human Development and Capabilities, Vol. 15, No. 23, pp. 132-146

Griffiths, J. (2014), The State of Finance for Developing Countries, 2014: An assessment of the scale of all sources of finance available to developing countries, European Network on Debt and Development (Eurodad) [online], retrieved from http://www.eurodad.org/files/pdf/54f98666925bf.pdf (accessed on 7 November 2015)

Hagenaars, A. (1991), 'The Definition and Measurement of Poverty' in Osberg, L (Ed.) Economic Inequality and Poverty: International Perspectives, Armonk NY: M. E. Sharpe

Hulme, D. (2015), The SDGs mark the end of development as poverty recution, Online, retrieved from http://developmentatmanchester.com/2015/10/01/the-sdgs-mark-the-end-of-development-aspoverty-reduction/ (accessed on 5 December 2015)

Hulme, D. and Shepherd, A. (2003), 'Conceptualizing Chronic Poverty', World Development, Vol. 31, No. 3, pp. $403-423$

James, H. (2012), The price of offshore revisited, London: Tax Justice Network

Kakwani, N. (2006), What is Poverty?, International Poverty Centre: UNDP, retrieved from http://www.ipcundp.org/pub/IPCOnePager22.pdf (accessed on 24 November 2012)

Kambhapati, U. S. (2007), Development and the Developing World, Cambridge: Polity

Kamruzzaman, P. (2015), Dollarisation of Poverty; Rethinking Poverty Beyond 2015, Basingstoke: Palgrave Macmillan

Kamruzzaman, P. (2014), Poverty Reduction Strategy in Bangladesh - Rethinking Participation in Policy-making, Bristol: Policy Press

Ki-moon, B. (2015), Sustainable development goals 'leave no one behind' in The Guardian [online], Retrieved from http://www.theguardian.com/global-development/2015/aug/03/ban-ki-moon-hails-sdgsagreed-by-193-nations-as-leaving-no-one-behind (accessed on 30 September 2015)

Koehler, G. (2015), 'Seven decades of 'development', And now what?', Journal of International Development, vol. 27, No. 6, pp. 733-751

Like-Minded Group (1990), Rural Poverty in Bangladesh: A Report to the Like-Minded Group, Dhaka: University Press Limited

Lister, R., (2004), Poverty, Chichester: Wiley

MacPherson, S. and Silburn, R (1998), 'The meaning and Measurement of Poverty' in J. Dixon, and D. Macarov, (Eds.), Poverty: A Persistent Global Reality, New York: Routladge

McCloskey, S. (2015), From MDGs to SDGs: We Need a Critical Awakening to Succeed, Policy \& Practice, Issue 20, pp. 189-197

Moore, H. L. (2015), 'Global Prosperity and Sustainable Development Goals', Journal of International Development, Vol. 27, No. 6, pp. 801-815

National Audit Office (NAO) (2012), 'How much support did the Government provide to UK Banks?', available: http://www.nao.org.uk/highlights/taxpayer-support-for-uk-banksfaqs/ (accessed 8 April 2015) 
Nicola Jo, Y. (2013), 'Psycho-social dimensions of poverty: when poverty becomes shameful', Critical Social Policy, Vol. 33, No. 3, pp. 514-531

Nussbaum, M. C. (2000), Women and Human Development: The Capabilities Approach, Cambridge: Cambridge University Press

Organisation for Economic Cooperation and Development (OECD) (2015), Aid Statistics - OECD, retrieved from http://www.oecd.org/dac/stats/data.htm (accessed on 1 November 2015)

Organization for Economic Co-operation and Development (OECD), Development Assistance Committee (DAC), (1996), Shaping the 21st Century: The Contribution of Development Co-operation, Paris: OECD/DAC

Oxford Poverty \& Human Development Initiative (OPHI) (2015), Global Multidimensional Poverty Index, retrieved from http://www.ophi.org.uk/multidimensional-poverty-index/ (accessed on 16 January 2015)

Palmer, E. (2015), 'Introduction: The Sustainable Development Goals Forum, Journal of Global Ethics, Vol. 11 , No. 1 , pp. 3-9

Pogge, T. (2013), 'Poverty, Hunger, and Cosmetic Progress' in M. Langford, A. Sumner, and A. Yamin (eds), The Millennium Development Goals and Human Rights, New York: Cambridge University Press

Pogge, T. and Sengupta, M. (2015), 'The Sustainable Development Goals: a plan for building a better world?', Journal of Global Ethics, Vol. 11, No.1, pp. 56-64

Poku, N. and Whitman, J. (2011), 'The Millennium Development Goals: challenges, prospects and opportunities', Third World Quarterly, Vol. 32, No. 1, pp. 3-8

Ravallion, M. (2010), 'A Reply to Reddy and Pogge' in S. Anand, P. Segal and J. E. Stiglitz (eds), Debates on the Measurement of Global Poverty, pp. 86 - 101, New York: Oxford University Press

Reddy, S. G. and Pogge, T. (2010), 'How Not to Count the Poor' in S. Anand, P. Segal and J. E. Stiglitz (eds), Debates on the Measurement of Global Poverty, pp. 42 - 85, New York: Oxford University Press

Roach, J. L. and Roach, J. K. (1972), Poverty, Selected Readings, Harmondsworth: Penguin Books

Rogoff, K. (1996), 'The Purchasing Power Parity Puzzle', Journal of Economic Literature, Vol. 34, No. 2, pp. $647-68$

Rowntree, B. S. (1941), Poverty and Progress: a Second Social Survey of York, Longman

Saith, A. (2006), 'From Universal Values to Millennium Development Goals: Lost in Translation', Development and Change, Vol. 37, No. 6, pp. 1167-99

Sanderson, S. (2004), 'Poverty and conservation: the new century's 'peasant question?", World Development, Vol. 33, No. 2, pp. 323-332

Scott, A. and Lucci, P. (2015), 'Universality and ambition in the Post-2015 development agenda: a comparison of global and national targets', Journal of international development, Vol. 27, No. 6, pp. 752-775

Sen, A. (1976), 'Poverty: An Ordinal Approach to Measurement', Econometrica, Vol. 44, pp. 219-31

Sexsmith, K. and McMichael, P. (2015), 'Formulating the SDGs: Reproducing or Reimagining StateCentered Development?', Globalizations, Vol. 12, No. 4, pp. 581-596

Shildrick, T., and MacDonald, R. (2013), 'Poverty talk: how people experiencing poverty deny their poverty and why they blame "the poor", The Sociological Review, Vol. 61, No. 2, pp. 285-303

Somavia, J. (2003), Working Out of Poverty, Geneva: ILO retrieved from http://www.ilo.org/public/english/standards/relm/ilc/ilc91/pdf/rep-i-a.pdf (accessed on 24 November 2012)

Sumner, A. and Tiwari, M. (2009), After 2015: International development policy at a crossroads, Basingstoke: Palgrave McMillan

Tomlinson, A. (2015), 'Peace and Post-2015 - Into The Home Stretch', Journal of Peacebuilding \& Development, Vol. 10, No.1, pp. 97-103

Townsend, P. (ed) (1970), The Concept of Poverty: Working Papers on Methods of Investigation and Life-Styles of the Poor in Different Countries, London: Heinemann

United Nations (UN), (2015a), Open Working Group proposal for Sustainable Development Goals [online], retrieved from https://sustainabledevelopment.un.org/focussdgs.html (accessed on 07 October 2015)

United Nations (UN), (2015b), Sustainable Development Goals [online], retrieved from https://sustainabledevelopment.un.org/?menu=1300, (accessed on 4 October 2015) 
United Nations (UN), (2015c), Interactive Dialogue 1 Ending poverty and hunger, [online] retrieved from https://sustainabledevelopment.un.org/content/documents/8141Interactive $\% 20$ Dialogue $\% 201$ $\% 20-\% 20$ Poverty $\% 20$ and $\% 20$ Hunger.pdf (accessed on 2 October 2015)

United Nations (UN) (2015d), Transforming our world: the 2030 Agenda for Sustainable Development, [online], https://sustainabledevelopment.un.org/post2015/transformingourworld (accessed on 8 October 2015)

United Nations (UN) (2015e), Final push for milestone event to finance development, [online], retrieved from https://www.un.org/development/desa/en/news/financing/final-push-for-ffd3.html accessed on 1 October 2015)

United Nations (UN), (2014), The Millennium Development Goals Report 2014, New York: United Nations Publications

United Nations (UN), (2014a), Millennium Development Goals, targets and indicators, 2014: statistical tables, retrieved from http://mdgs.un.org/unsd/mdg/Host.aspx?Content=Data/Trends.htm (accessed on 19 March 2015)

United Nations (UN), (2013), A New Global Partnership: Eradicate Poverty and Transform Economies through Sustainable Development, the Report of the High-Level Panel of Eminent Persons on the Post-2015 Development Agenda, New York: United Nations Publications

United Nations (UN) (1990), The international development strategy (IDS) for the fourth United Nations development decade (1991-2000), General Assembly 49th session. Res 199, retrieved from http://www.un.org/documents/ga/res/45/a45r199.htm

United Nations (UN), (1980), General Assembly Resolutions, A/RES/35/56 (1980)

United Nations (UN), (1970), General Assembly Resolutions, A/RES/2626 (1970)

United Nations (UN), (1961), General Assembly Resolutions, A/RES/1710 (1961)

UNdata (2015), Purchasing Power Parity (PPP) conversion factor, local currency unit into international dollar, Millennium Development Goals Database, retrieved from http://data.un.org/Data.aspx?d=MDG\&f=seriesRowID:699 (accessed on 28 March 2015)

United Nations Educational, Scientific and Cultural Organization (UNESCO), (2012), Poverty, retrieved from http://www.unesco.org/new/en/social-and-human-sciences/themes/internationalmigration/glossary/poverty/ (accessed on 24 November 2012)

UN System Task Team (UNTT) on post-2015 UN Development Agenda (2012), Realizing the Future We Want for All, New York: United Nations Publications

Unwin, T. (2007), 'No end to poverty', Journal of Development Studies, Vol. 43, No. 5, pp. 929 - 53

Vandemoortele, J. (2014), 'Post-2015 agenda: mission impossible?', Development Studies Research, Vol. 1, No. 1, pp. $223-232$

Vandemoortele, J. (2011), 'The MDG Story: Intention Denied', Development and Change, Vol 42, No. 1, pp 1 21

Vandemoortele, J. (2009) 'The MDG Conundrum: Meeting the Targets without Missing the Point', Development Policy Review, Vol 27, No. 4, pp. 355-71

Waage, J. (et. al.) (2010), 'The Millennium Development Goals: a cross-sectoral analysis and principles for goal setting after 2015', The Lancet, Vol. 376, pp. $991-1023$

Weber, H. (2015), 'Reproducing Inequalities through Development: The MDGs and the Politics of Method', Globalizations, Vol. 12, No 4, pp. 660-676

World Bank (2016), FAQs: Global Poverty Line Update, [online], retrieved from http://www.worldbank.org/en/topic/poverty/brief/global-poverty-line-faq (accessed on 17 April 2016)

World Bank (2013), The World Bank Group Goals: End Extreme Poverty and Promote Shared Prosperity, Washington, DC: World Bank

World Bank (2012), World Development Indicators 2012, Washington, DC: World Bank

World Bank (2008), Poverty - Overview, retrieved from www.worldbank.org/poverty (accessed on 29 May 2008)

Yiu, L. S. and Saner, R. (2014), 'Sustainable Development Goals and Millennium Development Goals: an analysis of the shaping and negotiation process', Asia Pacific Journal of Public Administration, Vol. 36, No. 2, pp. 89-107

Yunus, M. (2000), 'The Validity of Long-run Purchasing Power Parity in the South Asian Countries', The Bangladesh Development Studies, Vol. XXVI, No. 1, pp. 99 - 124 